\title{
Editorial Critical Issues in School Transition for Children and their Families
}

\author{
Hariclia Harriet Petrakos \\ Concordia University
}

As children make the transition to school they are faced with a new environment and the challenges associated with adjusting to a new setting. In North America, school transition typically refers to children making the transition from home to kindergarten or from an early childhood program to a kindergarten classroom. There is a growing emphasis on supporting the transition to school and providing multiple and varied opportunities for children and parents to become familiar with the school environment and to establish a collaborative approach to schooling. There is also growing evidence that transition practices involve parents and teachers working together to prepare children for school as well as involve schools to be inviting and welcoming to children and families (e.g., Dockett \& Perry, 2001; Early, Pianta, Taylor, \& Cox, 2001; La Paro, Pianta, \& Cox, 2000; Lo Casale-Crouch, Mashburn, Downer, \& Pianta, 2008). A systemic approach is therefore needed to ensure that transition practices do not only focus on children's individual skills, but also relationships between multiple contexts that children live in and interact with over time; these contexts often involve the children, parents, teachers, peers, and the wider community (Bronfenbrenner \& Morris, 1997; Kagan \& Neuman, 1998; Pianta \& Kraft-Sayre, 2003; Pianta \& Walsh, 1996; Rimm-Kaufman \& Pianta, 2000). This special issue focuses on critical issues related to school transition for children and their families. In addition, these papers include the perspectives of children, parents, and teachers and issues of diversity are considered as participants share their experiences on issues of school transition. Implications for policy and practice are also discussed.

In the first paper, Rethinking School Readiness, Farran calls for a critical discussion of the concept of school readiness. She argues that we cannot separate the child from his or her environment. Environments rich in language and math are important; however, very limited work has looked at the stress associated with large group settings in formal education. In addition, it is important to consider the impact of early intervention programs, teacher effectiveness, and classroom curriculum when assessing school readiness. It calls for viewing transition to school as a process and that the teacher's role involves the observation of children's skills in the classroom, the facilitation of children's emotional regulatory skills, and the development of curriculum designed to teach the underlying skills that children need to learn better in school.

In the second paper, School Readiness for Gifted Children, Porath raises some questions about what is meant by school readiness for children who are gifted. She challenges our notions 
of readiness and expands the definition of readiness to consider the "child-in-context" and take an individual developmental approach to understand the skills and abilities of children who are gifted learners. Educational environments that are flexible, developmentally appropriate and educationally challenging, rich in experience, and that support diversity in development are recommended.

In the third article, Impact of Impairment on Children with Special Needs at School Entry: Comparison of School Readiness Outcomes in Canada, Australia and Mexico, Janus describes data collected with the Early Development Instrument and compares children with special needs on school readiness domains. This study revealed that the children's specific learning and behaviour difficulties have more of an impact on overall development, whereas physical and sensory impairments seem to impact only the area related to the impairment. The comparison across countries revealed many similarities, but also some differences that may have been related to special education policies that affect the transition planning process.

In the fourth paper, Starting School with Special Needs: Issues for Families with Complex Support Needs as their Children Start School, Dockett, Perry, and Kearney challenge us to consider families with complex support needs whose children with special needs make the transition to school. Using a family-centered strength-based approach, they draw attention to the issues and concerns that parents have when they are navigating access to support services. They avoid the deficit approach in explaining the particular circumstances that impact families' daily lives (e.g., poverty) and show how starting school for their children often further reinforces the powerlessness families feel, and may even compound the difficulties they are encountering, raising their children with special needs.

In the fifth paper, Parents' and Teachers' Perceptions of Transition Practices in Kindergarten, Petrakos and Lehrer describe parents' and teachers' perceptions of transition practice as children make the transition to kindergarten. This study focused on how ministry and school board-mandated transition practices were perceived by teachers and parents with respect to family-school collaboration, advantages and disadvantages for families, parents' and teacher' roles, and involvement during the transition process.

Finally, in the sixth paper, Parent and Child Perceptions of Grade One Children's Outof-school Play, Lehrer and Petrakos remind us that the transition to school is marked by a decrease in amount of time children spend playing in the classroom and that out of school play is important to parents and children during this process. In this study, parents were interviewed to understand their beliefs about play and children's perspectives of play were also considered. This type of information may be valuable for teachers who are making decisions about the inclusion of play in the classroom and for educators who are designing play spaces for school-aged children. Such curriculum decisions may play a role in how children perceive their transition to school in the early years.

This special issue challenges us to think about school transition and readiness by taking stakeholders' perspectives (e.g., children, parents) and to view transition to school as a process that evolves over time and across contexts. In addition, the individual and familial characteristics of children cannot be ignored when preparing schools to welcome children and to make policy decisions that will impact the transition to school.

\section{References}

Bronfenbrenner, U., \& Morris, P. A. (1997). The ecology of developmental processes. In W. Damon \& R. M. Lerner (Eds.), Theoretical models of human development (pp. 993-1028). New York, NY: Wiley. 
Dockett, S., \& Perry, B. (2001). Starting school: Effective transitions. Retrieved from http://ecrp.uiuc.edu /v3n2/dockett.html

Early, D. M., Pianta, R. C., Taylor, L. C., \& Cox, M. J. (2001). Transition practices: Findings from a national survey of kindergarten teachers. Early Childhood Education Journal, 28(3), 199-206. doi:10.1023/A :1026503520593

Kagan, S. L., \& Neuman, M. J. (1998). Lessons from three decades of transition research. The Elementary School Journal, 98(4), 365-381. doi:10.1086/461902

La Paro, K. M., Pianta, R. C., \& Cox, M. J. (2000). Kindergarten teachers' reported use of kindergarten to first grade transition practices. Elementary School Journal, 101(1), 63-78, doi:10.1086/499659

Lo Casale-Crouch, J., Mashburn, A., Downer, J., \& Pianta, R. (2008). Pre-kindergarten teachers' use of transition practices and children's adjustment to kindergarten. Early Childhood Research Quarterly, 23(1), 124-139. doi:10.1016/j.ecresq.2007.06.001

Pianta, R. C., \& Kraft-Sayre, M. (2003). Successful kindergarten transition: Your guide to connecting children, families, \& schools. Baltimore, MD: Paul H. Brookes.

Pianta, R. C., \& Walsh, D. J. (1996). High-risk children in schools. New York, NY: Routledge.

Rimm-Kaufman, S. E., \& Pianta, R. C. (2000). An ecological perspective on the transition to kindergarten: A theoretical framework to guide empirical research. Journal of Applied Developmental Psychology, 21, 491-511. doi:10.1016/S0193-3973(00)00051-4

\section{Author's Note}

Correspondence concerning this article should be addressed to Hariclia Petrakos, Department of Education, Concordia University, 1455 de Maisonneuve west, LB-579, QC H3G 1M8. Email: HPETRAKOS@education.concordia.ca 